DOI:10.17951/h.2019.53.3.85-92

\begin{tabular}{lcc}
\hline & A N N A L E S \\
UNIVERSITATIS & MARIAE CURIE-SKŁODOWSKA \\
LUBLIN - POLONIA & \\
VOL. LIII, 3 & SECTIO H \\
\hline
\end{tabular}

\author{
MAREK SZTURO \\ marsz@uwm.edu.pl \\ University of Warmia and Mazury in Olsztyn, Faculty of Economic Sciences \\ 4 M. Oczapowskiego St, 10-719 Olsztyn, Poland \\ ORCID ID: https://orcid.org/0000-0001-7978-1089 \\ BOGDAN WŁODARCZYK \\ bogdan.wlodarczyk@uwm.edu.pl \\ University of Warmia and Mazury in Olsztyn, Faculty of Economic Sciences \\ 4 M. Oczapowskiego St, 10-719 Olsztyn, Poland \\ ORCID ID: https://orcid.org/0000-0002-8965-9957
}

\title{
New financial markets and their impact on raw material prices
}

Keywords: financial markets; commodity currencies; raw material markets

JEL: E42; E44; F45

How to quote this paper: Szturo, M., \& Włodarczyk, B. (2019). New financial markets and their impact on raw material prices. Annales Universitatis Mariae Curie-Skłodowska, sectio H-Oeconomia, Vol. 53, No. 3.

\begin{abstract}
The purpose of the study was to determine the impact of the Chinese financial market, which is a new market, on the exchange rates of commodity currencies and, thus, the prices of raw materials. For this purpose, an autoregressive distributed lag model (ARDL) was used. The results indicate that the Chinese stock market and futures market for the yuan (the Chinese Yuan Non-Deliverable Forward Transactions; CNY NDF market) had a significant impact on commodity currencies before the global financial crisis in 2008/09, then the effect widened to include more commodity currencies in the post-crisis period. Further evidence suggests that the CNY NDF market had a greater impact on commodity currencies than the Chinese stock market. Despite the significant position of the Chinese economy, research also indicates that the impact of Chinese financial markets on commodity currencies (raw material prices) is weaker than the impact of the US stock market and US dollar market.
\end{abstract}




\section{Introduction}

Driven by rapid economic growth, the Chinese economy's demand for raw materials and industrial goods has been growing dynamically over the past two decades. For this reason, China is playing an increasingly important role in determining global prices for raw materials and commodities. Considering the relatively short period of expansion of the Chinese economy, the Chinese markets (financial, including currency, and commodity and raw materials) can be considered as representatives of the category of new markets. This category also includes the financial markets of other countries of growing importance in the international arena, such as South Korea and India. The development of new economies of global importance creates new dependencies and influences shaping prices on commodity and currency markets. Taking the above into account, the aim of the research is to determine the impact of a new financial market, the Chinese market, on exchange rates and, thus, the prices of raw materials. This research supplements research focused on the financialisation of commodity markets.

\section{Literature review}

The issue of commodity currencies has already appeared in the publications of Hayek (1943) and Friedman (1951). They considered the standard of currency based on major commodities as part of the global economic stabilization system. Identification of the relationship between currencies and raw material prices was very much needed in this context. The early results of many studies, however, were not able to determine the exact character of this relationship (Meese \& Rogoff, 1983). Later, due to the development of research tools, the issue of dependence was clearly defined.

For example, it was found that commodity prices expressed with price indices and commodity price volatility showed a connection with the real exchange rates of raw material exporters (Chen, 2005). The condition that significantly increases the probability of such dependence was the share of export of goods in a given country, which should not be less than 20\% (Bodart, Candelon, \& Carpantier, 2012). In another study, indices for 44 goods and data on export of goods for 58 countries in the years 1980-2002 were used to identify the dependence. It was clear that the long-term correlation between the volatility of currencies and prices of commodities existed in $30 \%$ of the exporter countries surveyed (Cashin, Céspedes, \& Sahay, 2004). In this respect, research results relating to countries exporting crude oil stand out particularly. In relation to African countries in particular (Botswana, Kenya, and Tanzania), a positive correlation was found between higher oil prices and the appreciation of local currencies in the short term (Pershin, Molero, \& Gracia, 2016).

Nevertheless, some of the results of research on oil prices were not so clear, especially with respect to highly developed countries. For example, using monthly and quarterly data, it was found that oil prices were not correlated with the Cana- 
dian or US dollar rate (Ferraro, Rogoff, \& Rossi, 2015). In addition, under certain conditions of low volatility of oil prices, it was observed that real exchange rates of exporters were not conditioned by terms of trade (Dauvin, 2014).

It is very interesting to observe that the relationship between currencies and raw material prices can be directed both in one direction and the other. On the basis of research into the volatility of commodity currencies, it was found, with reference to small exporter countries, that it could be used to predict the price volatility of some goods (Chen, 2005).

The significant relationship between the volatility of spot and forward exchange rates means that they can be forecasted with greater accuracy over the longer term. In the case of commodities, the relationship between their spot and futures prices is less precise; nevertheless, it allows predicting short-term imbalances in demand and supply in these markets. In this context, it was no coincidence that there was identified a two-way Granger causality between the volatility of commodity prices and exchange rates for different time perspectives (Zhang, Dufour, \& Galbraith, 2016).

\section{Methodology and data sources}

The research scope covered four currencies: Australian dollar (AUD), New Zealand dollar (NZD), Canadian dollar (CAD), and Norwegian krone (NOK). The motive for the adoption of the above currencies were their classification by the International Monetary Fund as important currencies in the global currency market. In addition, determining them as commodity currencies results from the significant position of selected countries in the group of raw material exporters. As explained variables, the logarithmic daily rates of return of selected exchange rates to the US dollar (USD) were used.

Logarithmic, daily rates of return for the following selected explanatory variables were also adopted: the Commodity Research Bureau (CRB) Index, the Dow Jones Industrial Average (DJIA) Index, the US Dollar Index, the Chinese Yuan Non-Deliverable Forward Transactions (CNY NDF), and Shanghai Composite Index prices. The study covered the period from 2006 to 2018. The year 2008 was chosen as a borderline in the pre-crisis period (2006-2008) and after the crisis (2009-2018). Table 1 presents descriptive statistics for four adopted time series of returns for selected currencies. All data in terms of variable values was obtained from the Bloomberg database.

Table 1. Descriptive statistics for datasets

\begin{tabular}{|l|c|c|c|c|c|c|c|c|c|}
\hline & Mean & Maximum & Minimum & $\begin{array}{c}\text { Standard } \\
\text { deviation }\end{array}$ & Skewness & Kurtosis & $\begin{array}{c}\text { Jarque- } \\
\text { Bera value }\end{array}$ & $P$-value & $\begin{array}{c}\text { Number of } \\
\text { observations }\end{array}$ \\
\hline$r_{\text {aud }, t}$ & 0.0001 & 0.148 & -0.072 & 0.012 & 1.821 & 34.682 & 96534.7 & $<0.001$ & 3,064 \\
\hline$r_{\text {cad }, t}$ & 0.0002 & 0.067 & -0.043 & 0.005 & 0.315 & 12.533 & 7382.6 & $<0.001$ & 3,064 \\
\hline$r_{\text {nok }, t}$ & 0.0001 & 0.092 & -0.059 & 0.008 & 0.448 & 12.154 & 8734.4 & $<0.001$ & 3,064 \\
\hline
\end{tabular}


Pobrane z czasopisma Annales H - Oeconomia http://oeconomia.annales.umcs.pl

Data: 26/04/2023 14:36:44

MAREK SZTURO, BOGDAN WŁODARCZYK

\begin{tabular}{|l|c|c|c|c|c|c|c|c|c|}
\hline & Mean & Maximum & Minimum & $\begin{array}{c}\text { Standard } \\
\text { deviation }\end{array}$ & Skewness & Kurtosis & $\begin{array}{c}\text { Jarque- } \\
\text { Bera value }\end{array}$ & $P$-value & $\begin{array}{c}\text { Number of } \\
\text { observations }\end{array}$ \\
\hline$r_{n z d, t}$ & 0.0001 & 0.089 & -0.065 & 0.012 & 0.489 & 11.421 & 5121.2 & $<0.001$ & 3,064 \\
\hline$r_{\text {crb, }, t}$ & 0.0003 & 0.046 & -0.148 & 0.016 & -1.103 & 15.321 & 19624.2 & $<0.001$ & 3,064 \\
\hline$r_{\text {usd }, t}$ & 0.0001 & 0.061 & -0.043 & 0.007 & 0.327 & 9.958 & 4833.3 & $<0.001$ & 3,064 \\
\hline$r_{d j, t}$ & 0.0005 & 0.112 & -0.121 & 0.014 & -0.386 & 13.422 & 13011.3 & $<0.001$ & 3,064 \\
\hline$r_{n d f, t}$ & 0.0007 & 0.041 & -0.031 & 0.002 & 1.039 & 25.114 & 46154.8 & $<0.001$ & 3,064 \\
\hline$r_{\text {shci, }, t}$ & 0.0010 & 0.087 & -0.117 & 0.016 & -0.601 & 7.211 & 1982.9 & $<0.001$ & 3,064 \\
\hline
\end{tabular}

Source: Authors' own study based on the Bloomberg database.

The study used the autoregressive distributed lag (ARDL) model (Pesaran, Shin, $\&$ Smith, 2001). The model can be used for a wide cross-section of data (Pesaran \& Smith, 1998). In addition, an error correction model (ECM) was used that integrates short-term corrections with long-term sustainability without losing long-term information (Pesaran \& Shin, 1996).

\section{Research results}

The ARDL approach can be applied to integrated variables. To verify the null hypothesis with the presence of the unit element, the augmented Dickey-Fuller test and the Phillips-Perron test were used. In addition, the null hypothesis, that is, the lack of a long-term relationship between variables, was confirmed.

The long-term balance between the variables was determined using the ARDL approach for the four commodity currencies analyzed. The results are presented in Table 2. The coefficients for the CRB Index are negative and statistically significant for two periods of research. This confirms the existence of a causal relationship between commodity prices and commodity exchange rates. In addition, it can be observed that the coefficients for the CRB Index for all currencies examined were between 0.14 and 0.2 for the second period. This means that a $1 \%$ decline in the CRB Index led to a devaluation of the commodity currencies, ranging from $0.14 \%$ to $0.2 \%$ in the long run. At the same time, the coefficients for the second period were higher than the coefficients for the first period, which means that commodity prices had a greater impact on the exchange rates of commodities in the period after the 2008 financial crisis than before it.

Table 2. Parameters of the long-term autoregressive distributed lag model

\begin{tabular}{|c|c|c|c|c|c|c|c|c|}
\hline & \multicolumn{2}{|c|}{ AUD } & \multicolumn{2}{|c|}{ NZD } & \multicolumn{2}{|c|}{ CAD } & \multicolumn{2}{|c|}{$\mathrm{NOK}$} \\
\hline & $\begin{array}{c}\text { Before the } \\
\text { crisis }\end{array}$ & $\begin{array}{l}\text { After the } \\
\text { crisis }\end{array}$ & $\begin{array}{c}\text { Before the } \\
\text { crisis }\end{array}$ & $\begin{array}{l}\text { After the } \\
\text { crisis }\end{array}$ & $\begin{array}{c}\text { Before the } \\
\text { crisis }\end{array}$ & $\begin{array}{l}\text { After the } \\
\text { crisis }\end{array}$ & $\begin{array}{c}\text { Before the } \\
\text { crisis }\end{array}$ & $\begin{array}{c}\text { After the } \\
\text { crisis }\end{array}$ \\
\hline$r_{c r b, t-1}$ & $-0.152 * * *$ & $-0.203 * * *$ & $-0.099 * * *$ & $-0.146^{* * *}$ & $-0.112 * * *$ & $-0.169 * * *$ & $-0.148 * * *$ & $-0.157 * * *$ \\
\hline$r_{u s d x, t-1}$ & $-0.298 * * *$ & $-0.312 * * *$ & $-0.317 * * *$ & $-0.232 * * *$ & $-0.212 * * *$ & $-0.206 * * *$ & $-0.083 * * *$ & $-0.075 * * *$ \\
\hline$r_{d j i, t-I}$ & $0.588 * * *$ & $0.483 * * *$ & $0.602 * * *$ & $0.712 * * *$ & $0.373 * * *$ & $0.338 * * *$ & $0.985 * * *$ & $0.796 * * *$ \\
\hline
\end{tabular}


Pobrane z czasopisma Annales H - Oeconomia http://oeconomia.annales.umcs.pl Data: 26/04/2023 14:36:44

NEW FINANCIAL MARKETS AND THEIR IMPACT ON RAW MATERIAL PRICES

\begin{tabular}{|l|c|c|c|c|c|c|c|c|}
\hline & \multicolumn{2}{|c|}{ AUD } & \multicolumn{2}{c|}{ NZD } & \multicolumn{2}{c|}{ CAD } & \multicolumn{2}{c|}{ NOK } \\
\hline & $\begin{array}{c}\text { Before the } \\
\text { crisis }\end{array}$ & $\begin{array}{c}\text { After the } \\
\text { crisis }\end{array}$ & $\begin{array}{c}\text { Before the } \\
\text { crisis }\end{array}$ & $\begin{array}{c}\text { After the } \\
\text { crisis }\end{array}$ & $\begin{array}{c}\text { Before the } \\
\text { crisis }\end{array}$ & $\begin{array}{c}\text { After the } \\
\text { crisis }\end{array}$ & $\begin{array}{c}\text { Before the } \\
\text { crisis }\end{array}$ & $\begin{array}{c}\text { After the } \\
\text { crisis }\end{array}$ \\
\hline$r_{n d f, t-1}$ & $0.295^{* * *}$ & $0.681 * * *$ & $0.336^{* * *}$ & $0.428^{* * *}$ & 0.026 & $0.189 * * *$ & 0.088 & $0.196^{* * *}$ \\
\hline$r_{\text {shci, } t-1}$ & $-0.022^{* * *}$ & $-0.028 * * *$ & -0.013 & $-0.025 * * *$ & -0.003 & -0.001 & $-0.015^{* * *}$ & $-0.026^{* * *}$ \\
\hline $\begin{array}{l}\text { Number of } \\
\text { observations }\end{array}$ & 724 & 2,341 & 724 & 2,341 & 724 & 2,341 & 724 & 2,341 \\
\hline$R$-squared & 0.71 & 0.82 & 0.54 & 0.78 & 0.65 & 0.82 & 0.76 & 0.77 \\
\hline
\end{tabular}

Source: Authors' own study based on Bloomberg database.

Note: AUD - Australian dollar; CAD - Canadian dollar; NOK - Norwegian krone; NZD - New Zealand dollar.

*** $1 \%$ significance level

The USD Index had a positive correlation with the currencies in both periods analyzed (before and after the crisis). The growth of the USD Index led to the depreciation of commodity currencies. This means that the exchange rates of commodity currencies changed in the same direction as the USD Index. It can be concluded that there was a positive impact of changes in global currency exchange related to changes in economic activity on changes in commodity currency rates.

The results of the research also indicate that the increase of the US stock market (the DJIA) led to the appreciation of commodity currencies in both periods (before and after the crisis). Considering theoretical interpretations, the long-term growth of the US stock market reduced risk aversion among investors in global markets, which resulted in the appreciation of the CRB Index and the USD Index. This, in turn, influenced the exchange rates of raw materials. A further observation of the study was that the impact of the US stock market on commodity currencies was statistically significant even after eliminating the impact of the above variables. This shows the strength of this market's impact on commodity currencies.

The rate of return of the Shanghai Composite Index had a statistically significant effect on the AUD and NOK in the first period, and on the AUD, NZD, and NOK in the second period. However, its impact on the CAD was not statistically significant for either period (before or after the crisis).

The coefficients for the Shanghai Composite Index were slightly higher in the second period than in the first period for three of the four commodity currencies, the CAD being the exception. At the same time, for the AUD, the $1 \%$ increase in the Chinese stock market index only contributed to an increase in the rate of the currency by $0.02 \%$.

Given the above, the growth in the new global stock market in Shanghai had less impact on commodity currencies than the New York stock market. This is an interesting conclusion, because it shows there is still significant strength of the US financial market. Despite the strength of the Chinese economy and the demand for raw materials by Chinese companies, the value of the Shanghai stock market was not as important as its US counterpart. 
The coefficients for the forward rate for the Chinese yuan (CNY) were statistically significant in the first period only for two commodity currencies (AUD and NZD). However, in the second period, these rates were statistically significant for all currencies tested. This means that its value as an explanatory variable increased as a result of the financial crisis. The results indicate that the CNY NDF rate has become an important factor that may be the reason for fluctuations in the prices of some commodity currencies. A $1 \%$ increase in the CNY NDF rate leads to an appreciation of commodity currencies in the range $0.18 \%$ to $0.68 \%$. Thus, the impact of the CNY NDF variable on commodity currencies was significant in the periods under review, especially when compared to the situation on the Shanghai Stock Exchange. The NDF rate is important as a measure of market expectations regarding the exchange rate of the Chinese currency (Liu \& Pauwels, 2012).

Chinese macroeconomic forecasts, such as economic growth, changes in money supply and balance of trade, are important factors of the CNY NDF rate of return. Strong macroeconomic fundamentals and optimistic expectations regarding the future of the Chinese economy are proving to be important reasons for the increase in CNY spot rates and CNY NDF transaction rates. For this reason, fluctuations in CNY markets, including the NDF market, can be seen as an important prognosis of China's economic outlook, and, thus, the demand of the Chinese economy for industrial goods.

Table 3. Parameters of the short-term autoregressive distributed lag model

\begin{tabular}{|c|c|c|c|c|c|c|c|c|}
\hline & \multicolumn{2}{|c|}{ AUD } & \multicolumn{2}{|c|}{ NZD } & \multicolumn{2}{|c|}{ CAD } & \multicolumn{2}{|c|}{$\mathrm{NOK}$} \\
\hline & $\begin{array}{c}\text { Before the } \\
\text { crisis }\end{array}$ & $\begin{array}{l}\text { After the } \\
\text { crisis }\end{array}$ & $\begin{array}{c}\text { Before the } \\
\text { crisis }\end{array}$ & $\begin{array}{l}\text { After the } \\
\text { crisis }\end{array}$ & $\begin{array}{c}\text { Before the } \\
\text { crisis }\end{array}$ & $\begin{array}{l}\text { After the } \\
\text { crisis }\end{array}$ & $\begin{array}{c}\text { Before the } \\
\text { crisis }\end{array}$ & $\begin{array}{l}\text { After the } \\
\text { crisis }\end{array}$ \\
\hline$\Delta r_{i, t-1}$ & & & & & & & & $0.049^{* * *}$ \\
\hline$\Delta r_{c r b, t}$ & $-0.151 * * *$ & $-0.238 * * *$ & $-0.101 * * *$ & $-0.172 * * *$ & $-0.104 * * *$ & $-0.186 * * *$ & $-0.112 * * *$ & $-0.214 * * *$ \\
\hline$\Delta r_{d j i, t}$ & $-0.109 * * *$ & $-0.112 * * *$ & $-0.142 * * *$ & $-0.119 * * *$ & $-0.068 * * *$ & $-0.073 * * *$ & -0.017 & -0.011 \\
\hline$\Delta r_{d j i, t-1}$ & & $0.076^{* * *}$ & & & & $0.021 * * *$ & & \\
\hline$\Delta r_{d j i, t-2}$ & & $0.041^{*}$ & & & & & & \\
\hline$\Delta r_{d j i, t-3}$ & & $0.058 * * *$ & & & & & & \\
\hline$\Delta r_{u s d x, t}$ & $0.583 * * *$ & $0.442 * * *$ & $0.448 * * *$ & $0.489 * * *$ & $0.375 * * *$ & $0.323 * * *$ & $0.926 * * *$ & $0.789 * * *$ \\
\hline$\Delta r_{u s d x, t-I}$ & & & & $-0.115 * * *$ & & & & \\
\hline$\Delta r_{n d f, t}$ & $0.281 * * *$ & $0.802 * * *$ & $0.298 * * *$ & $0.518 * * *$ & 0.031 & $0.236^{* * *}$ & 0.118 & $0.253 * * *$ \\
\hline$\Delta r_{\text {shci, } t}$ & $-0.031 * * *$ & $-0.035 * * *$ & -0.021 & $-0.029 * * *$ & -0.003 & -0.001 & $-0.025 * *$ & $-0.032 * * *$ \\
\hline $\mathrm{ECM}_{\mathrm{t}-1}$ & $-0.958 * * *$ & $-1.302 * * *$ & $-0.953 * * *$ & $-1.142 * * *$ & $-0.984 * * *$ & $-1.123 * * *$ & $-1.124 * * *$ & $-1.265 * * *$ \\
\hline $\begin{array}{l}\text { Number of } \\
\text { observations }\end{array}$ & 724 & 2,341 & 724 & 2,341 & 724 & 2,341 & 724 & 2,341 \\
\hline$R$-squared & 0.68 & 0.79 & 0.61 & 0.75 & 0.66 & 0.82 & 0.77 & 0.81 \\
\hline CUSUM & Stable & Stable & Stable & Stable & Stable & Stable & Stable & Stable \\
\hline CUSUMSQ & Stable & Stable & Stable & Stable & Stable & Stable & Stable & Stable \\
\hline
\end{tabular}

Source: Authors' own study based on the Bloomberg database.

Note: AUD - Australian dollar; CAD - Canadian dollar; CUSUM - cumulative sum test; CUSUMSQ - cumulative sum squares test; NOK - Norwegian krone; NZD - New Zealand dollar.

*** $1 \%$ significance level; * $10 \%$ significance level 
The results of the short-term analysis and the coefficients relating to the error correction parameters are presented in Table 3. The coefficient values are similar to the corresponding values for the long-term analysis. Delayed USD Index and DJIA Index variables had a statistically significant effect on commodity currencies, while the impact of other variables was small. The results suggest that the US stock market and the USD foreign exchange market have a delayed effect on some commodity currencies, while the impact of financial markets in China declines relatively quickly.

The value of the coefficient for the error correction model (ECM) is in many cases greater than -1.00 , which means a quick adjustment of raw material prices to equilibrium. In fact, almost all imbalances approach the long-term balance within one period (i.e. one day). In addition, the course of cumulated sum (CUSUM) and CUSUM squares test statistics is within critical limits, which means that all coefficients in the error correction model are stable.

\section{Conclusions}

The research results presented are preliminary and constitute one of the elements determining the direction of in-depth research. Taking into account the changes taking place in the global economy, the impact of new financial markets on the raw material markets was verified. The empirical analysis was focused on the US financial market and the Chinese financial market. In addition, efforts were made to include the impact of the financial crisis by adopting a specific time range. The results obtained were not a surprise for the most part.

It was found that the Chinese financial market had a significant impact on commodity currencies both before and after the financial crisis. This influence is growing systematically, which is a manifestation of China's growing expansion in commodity markets. It was also not surprising that the forward market of the Chinese currency had stronger influence than the Chinese stock market. This is due to the forecasting character of the forward market of the Chinese currency.

However, despite the dynamic economic development of China, the impact of Chinese markets was weaker than the impact of US markets (stock and dollar markets). This means that the markets of commodity currencies and related commodity markets are still dominated by the influence of the US economy. This influence seems to be largely related to the nature of US markets as a kind of measure of the global economic situation. Raw materials and currencies associated with them constitute an important element of the process of creating value in the real sphere of the economy, and American markets, therefore, still better anticipate the opportunities and threats facing entities involved in commodity markets.

The results of the study also suggest that the analysis of the volatility of commodity currencies must take into account the impact of financial markets. An in- 
teresting extension of the study would be to identify in the future the manner in which other financial markets are related to commodity markets through commodity exchange rates.

\section{References}

Bodart, V., Candelon, B., \& Carpantier, J. (2012). Real exchanges rates in commodity producing countries: A reappraisal. Journal of International Money and Finance, 31(6), 1482-1502. doi:10.1016/j.jimonfin.2012.02.012

Cashin, P., Céspedes, L.F., \& Sahay, R. (2004). Commodity currencies and the real exchange rate. Journal of Development Economics, 75(1), 239-268. doi:10.1016/j.jdeveco.2003.08.005

Chen, Y.-C. (2005). Exchange rates and fundamentals: Evidence from commodity currencies. University of Washington Working Paper. Retrieved from http://faculty.washington.edu/yuchin/Papers/ERF_ychen. pdf [access: 10.02.2019].

Dauvin, M. (2014). Energy prices and the real exchange rate of commodity-exporting countries. The International Economy, 137, 52-72. doi:10.1016/j.inteco.2013.11.001

Ferraro, D., Rogoff, K., \& Rossi, B. (2015). Can oil prices forecast exchange rates? An empirical analysis of the relationship between commodity prices and exchange rates. Journal of International Money and Finance, 54, 116-141. doi:10.1016/j.jimonfin.2015.03.001

Friedman, M. (1951). Commodity-reserve currency. Journal of Political Economy, 59(3), $203-232$.

Hayek, F.A. (1943). A commodity reserve currency. The Economic Journal, 53(210-211), 176-184.

Liu, L.-G., \& Pauwels, L. (2012). Do external political pressures affect the Renminbi exchange rate? Journal of International Money and Finance, 31, 1800-1818. doi:10.1016/j.jimonfin.2012.04.001

Meese, R., \& Rogoff, K. (1983). Empirical exchange rate models of the seventies: Do they fit out of sample? Journal of International Economics, 14(1-2), 3-24. doi:10.1016/0022-1996(83)90017-X

Pershin, V., Molero, J.C., \& Gracia, D. (2016). Exploring the oil prices and exchange rates nexus in some African economies. Journal of Policy Modeling, 38(1), 166-180. doi:10.1016/j.jpolmod.2015.11.001

Pesaran, M.H., \& Shin, Y. (1996). Cointegration and speed of convergence to equilibrium. Journal of Econometrics, 71, 117-143. doi:10.1016/0304-4076(94)01697-6

Pesaran, M.H., \& Smith, R. (1998). Structural analysis of cointegration VARs. Journal of Economic Surveys, 12(5), 471-505. doi:10.1111/1467-6419.00065

Pesaran, M.H., Shin, Y., \& Smith, R. (2001). Bounds testing approaches to the analysis of level relationships. Journal of Applied Econometrics, 16(3), 289-326. doi:10.1002/jae.616

Zhang, H.J., Dufour, J.-M., \& Galbraith, J.W. (2016). Exchange rates and commodity prices: Measuring causality at multiple horizons. Journal of Empirical Finance, 36, 100-120.

doi:10.1016/j.jempfin.2015.10.005 